KS. WoJCIECH OSIAL

Wyższe Seminarium Duchowne

ŁOWICZ

\title{
ZARYS HISTORII NAUCZANIA I WYCHOWANIA RELIGIJNEGO MLODZIEŻY
}

Celem podejmowanej refleksji jest ukazanie procesu formacji religijnej młodzieży na przestrzeni dwudziestu wieków historii Kościoła. Rozważania mają charakter ogólnego zarysu, gdyż mamy do czynienia z ogromnie długim przedziałem czasowym obejmującym wiele epok naznaczonych różnorodnymi uwarunkowaniami religijnymi i historyczno-kulturowymi. Ma się na uwadze działania formacyjne, które wchodzą w zakres nauczania i wychowania religijnego. Przedmiotem analizy jest bardzo złożona rzeczywistość katechetyczna i pastoralna Kościoła, w której katecheza splata się z różnymi formami duszpasterstwa młodzieży. Całość ukazuje bogactwo inicjatyw i działań na rzecz młodzieży, które mogą być inspiracją dla współczesnych poszukiwań pastoralnych i katechetycznych.

\section{Młodzi w Kościele starożytnym}

W pierwszych wiekach Kościoła nie istniała formacja młodzieży, która na mocy decyzji Kościoła byłaby oddzielnym działaniem edukacyjnym skierowanym bezpośrednio do ludzi młodych. Brak takiej formacji wynikał przynajmniej z dwóch powodów. Po pierwsze młodych traktowano jak dorosłych. Ich formacja była włączona w całość wysiłków ewangelizacyjnych pierwszego Kościoła. Nauczano wszystkich tych, którzy byli gotowi przyjąć wezwanie do nawrócenia i przygotować się do chrztu. Wystarczyła zdolność do dojrzałego i odpowiedzialnego przyjęcia głoszonego kerygmatu i życia w przyjętej wierze. Świadectwem takich działań jest katecheza czasów apostolskich i okresu katechumenatu.

Druga racja wiąże się ze specyficznym spojrzeniem chrześcijaństwa na młody wiek człowieka, szczególnie czas dziecięcy. Można w pewnym sensie mówić o braku zainteresowania wiekiem dziecięcym i młodzieńczym. Dzieciństwo i wiek młodzieńczy postrzegano jako etap rozwoju, który należało jak najszybciej pokonać w drodze ku dorosłości. Według Ojców Kościoła liczył się przede wszystkim szybki wzrost i rozwój duchowy człowieka. Była to droga przeskoku czy ucieczki

1 Zob. R. Murawski, Historia katechezy. Cz. I. Katecheza w pierwszych wiekach, Warszawa 2011. 
z dzieciństwa ku dorosłości². Tego rodzaju przekonanie znajdowało uzasadnienie teologiczne. Nie ważne były etapy rozwoju człowieka wyznaczone czasem, gdyż najważniejszą rzeczą była dojrzałość w wierze. Teraźniejszość odsyłała ku wieczności. Liczyła się głównie przyszłość wprowadzająca do wieczności i pełnej jedności z Bogiem. Jeśli natomiast wracano do dzieciństwa, to głównie po to, aby widzieć w nim model właściwej relacji człowieka do Boga. Człowiek dążący do życia wiecznego winien stawać się ufny jak dziecko, mieć ewangeliczną prostotę dziecka względem Boga. Ponadto Kościół pierwszych wieków, jakkolwiek formował człowieka, to jednak posiadał stosunkowo małą wrażliwość pedagogiczną. Dzieciństwo było obrazem wszystkiego co cielesne i materialne, dlatego też w wychowaniu nie poświęcano mu większej uwagi ${ }^{3}$.

Chociaż trudno jest mówić o istnieniu specjalnej formacji młodzieży w Kościele starożytnym, to jednak można zauważyć wiele różnych działań duszpasterskich i katechetycznych, które są wyrazem troski o ludzi młodych. Jest to zrozumiałe, gdyż Kościół jako Matka przygarniał wszystkich i tym samym nie mógł pozostawać obojętny wobec młodzieży.

\subsection{Formacja i świadectwo wiary}

Bezpośrednie wprowadzenie młodych w wiarę dokonywało się ramach instytucji katechumenatu. Młodzież przygotowywano razem z dorosłymi do przyjęcia chrztu i późniejszego życia we wspólnocie Kościoła. Podstawowym środowiskiem formacji była liturgia. Formowano głównie przez głoszenie i wyjaśnianie Słowa Bożego. Przyjmowana wiara musiała być w wielu przypadkach bardzo silna, skoro zauważa się znaczącą liczbę młodych męczenników w pierwszych wiekach. Można wskazać chociażby na św. Agnieszkę (12 lat), św. Taryscjusza (13 lat), św. Agatę (16 lat), św. braci Donacjana i Rogacjana nazywanych z racji młodego wieku „dziećmi nantejskimi”. Męczeństwo porównywano do odważnej postawy żołnierza i atlety. Męczennicy jak żołnierze i atleci podejmowali walkę i wszelki trud dla zwycięstwa Chrystusa. Tertulian nazywa męczenników żołnierzami Boga ${ }^{4}$.

Wśród młodych rodzi się model życia w czystości i dziewictwie, którego celem było pełne oddanie się Chrystusowi dla zbawienia własnej duszy (dziewice i wdowy). Liczba młodych wybierających stan życia w czystości była duża. Wartość

2 Zob. A. Giallongo, Il bambino mediewale, Bari 1990, s. 18.

3 Zob. O. Pasquato, Pastorale giovanile (storia-1), w: Dizionario di pastorale giovanile, red. M. Midali, R. Tonelli, Leumann (Torino) 1992, s. 769-770.

4 Zob. Tertulian, Do męczenników, 3, 1, w: Tertulian, Wybór pism, tłum. E. Stanula, Warszawa 1970 (Pisma Starochrześcijańskich Pisarzy V). 
takich wyborów podkreślali w swoich pismach Tertulian, św. Cyprian, św. Atanazy, św. Jan Chryzostom, św. Ambroży z Mediolanu.

\subsection{Wyzwania szkoły i kultury antycznej}

Wielkim wyzwaniem dla Kościoła była bogata rzeczywistość nauczania i wychowania w ówczesnych szkołach, które kształciły młodzież w duchu kultury antycznej, nie zawsze zgodnej z wartościami i zasadami chrześcijaństwa. Nie było jeszcze szkół chrześcijańskich powoływanych jako przeciwwaga dla szkoły klasycznej. Wychowanie chrześcijańskie musiało więc zmierzać się z formacją młodzieży opartą na zasadach wypracowanych przez greckie gimnazja i łacińskie collegia iuvenum. Nie było jednak walki z instytucją szkoły antycznej. Obcy był podział na świecką kulturę klasyczną i kulturę religijną, zarezerwowaną tylko dla chrześcijan. Istniała swoista osmoza pomiędzy klasyczną kulturą grecko-rzymską i kulturą chrześcijańską. Byli nauczyciele chrześcijańscy, którzy nauczali pogan, i chrześcijanie, którzy uczęszczali do szkół pogańskich ${ }^{5}$. Krytykowano pogańskie treści nauczania, ale nie kwestionowano potrzeby ogólnego wykształcenia ${ }^{6}$. Młodzi z rodzin chrześcijańskich byli kształceni w zakresie wiedzy ogólnej w klasycznych szkołach. Znajomość kultury świeckiej była przecież konieczna dla podejmowania funkcji administracyjnych i społecznych. Zachęcano młodych, aby przyjmowali to co dobre w kulturze klasycznej i odrzucali nauczanie niezgodne $\mathrm{z}$ doktryną Kościoła. Tak czynił św. Bazyli Wielki w swojej słynnej Mowie do młodzieńców ${ }^{7}$. Negatywny wpływ szkół świeckich próbowano niwelować przez solidną formację młodych we wspólnotach kościelnych i w rodzinach.

Pojawiają się jednocześnie pewne działania mające na celu formację chrześcijańską. Próbuje się wprowadzać myśl chrześcijańską w środowisko szkół publicznych. W Dziejach Apostolskich czytamy, że Paweł będąc w Efezie rozprawiał w szkole Tyrannosa, nauczyciela gramatyki i retoryki (zob. Dz 19, 9). Nie potępiano nauczycieli chrześcijańskich uczących w tych szkołach. W Tradycji Apostolskiej

5 Zob. A. Quacquarelli, Scuola e kultura nei primi secoli cristiani, w: Nuove questioni di storia della pedagogia, Vol. I, Brescia 1977, s. 296-299.

6 Zob. H.-I. Marrou, Historia wychowania w starożytności, Warszawa 1969, s. 444-447. Potrzebę ogólnego wykształcenia dobrze wyjaśnia Tertulian, kiedy pyta: „Czy możemy odrzucić studia świeckie, bez których niemożliwe jest zajmowanie się naukami Bożymi?” Zarazem odpowiada w ten sposób: „Umiejętność pisania i czytania jest konieczna (...). Nie można zdobywać części wiedzy, lekceważąc inne umiejętności. Chrześcijanin w większym stopniu stara się zaś o zdobywanie wiedzy o literaturze niż o jej wykładanie". Tertulian, O bałwochwalstwie, 10, tłum. A Strzelecka, Poznań 2005 (Pisma Ojców Kościoła XXVIII).

7 Bazyli Wielki, Mowa do młodzieńców, jaki mogq odnieść pożytek z czytania książek pogańskich, w: Wybór homilii i kazań. Tłumaczył i wstępem opatrzył T. Sinko, Kraków 1947, s. 213-130. 
Hipolita Rzymskiego podaje się co prawda, że nauczyciel nie powinien nauczać nauk tego świata, ale stwierdza się jednocześnie, że jeśli nie ma innego zawodu dającego mu utrzymanie, wówczas jest usprawiedliwiony ${ }^{8}$. Warto też zauważyć, że wśród wychowanków nauczycieli pogańskich są wielcy uczeni chrześcijańscy tacy jak Atenagoras, Klemens Aleksandryjski, Ojcowie Kapadoccy, Jan Chryzostom, Tertulian, Cyprian czy Augustyn. Co więcej, podobne szkoły gramatyki mogli też otwierać nauczyciele chrześcijańscy. Orygenes otworzył własną szkołę gramatyki w 202/203 roku i prowadził w niej nauczanie katechetyczne z polecenia biskupa Demetriusza?.

Rodzą się pierwsze inicjatywy organizowania systematycznej nauki chrześcijańskiej. Rolę pierwszych nauczycieli pełnili świeccy, którzy jakkolwiek nie posiadali oficjalnej misji nauczania, to jednak byli uznawani przez Kościół ${ }^{10}$. W II wieku takim nauczycielem był Ptolemeusz, który nauczał doktryny Chrystusa ${ }^{11}$. Zaczęły powstawać pierwsze szkoły katechetyczne. Już w połowie II wieku taką szkołę założył św. Justyn w Rzymie. Bardzo słynne były w szkoły prowadzone przez Klemensa Aleksandryjskiego i Orygenesa w początkach trzeciego wieku ${ }^{12}$.

\subsection{Religijne i wychowawcze zadania rodziców}

Ważnym środowiskiem wychowawczym i zarazem niwelującym wpływy kultury pogańskiej była rodzina. Wraz ze wzrostem nawróceń na chrześcijaństwo zwiększała się liczba rodzin chrześcijańskich prowadzących głęboką formację religijno -moralną młodego pokolenia. Piękną definicję rodziny podaje św. Jan Chryzostom stwierdzając, że „dom jest małym Kościołem”" ${ }^{\text {. W }}$ rodzinie jak w Kościele młody człowiek był wychowywany w wierze i zasadach moralności chrześcijańskiej.

\footnotetext{
8 Zob. Hipolit Rzymski, Tradycja Apostolska, 16. Wstęp, przekład, komentarz H. Paprocki, Studia Theologica Varsaviensia 1(1976).

9 Zob. Euzebiusz z Cesarei, Historia Kościelna, VI, 3, 3; 15. Z greckiego tłumaczył, zaopatrzył wstępem, objaśnieniami, skorowidzami A. Lisiecki, Poznań 1924 (Pisma Ojców Kościoła 3).

10 Zob. G. Bardy, Les écoles romaines au second siècle, "Revue d'histoire ecclésiastique" 3(1932), s. 504.

11 Zob. Justyn Męczennik, II Apologia, 1, 9. w: Pierwsi apologeci greccy, przekład, wstęp i komentarze L. Misiarczyk, red. J. Naumowicz, Kraków 2004 (Biblioteka Ojców Kościoła 24).

12 Według relacji Euzebiusza z Cesarei szkoła Orygenesa miała dwa poziomy: poziom podstawowy katechetyczny przeznaczony dla pobierających pierwsze nauki wiary, i poziom wyższy zajmujący się „kształceniem uczniów dalej posuniętych”. Zob. Euzebiusz z Cesarei, Historia Kościelna VI, 15. Szerzej na temat szkół katechetycznych w starożytności zob. R. Murawski, Historia katechezy. Cz. I. Katecheza w pierwszych wiekach, dz. cyt., s. 178-183.

13 Św. Jan Chryzostom, In Epistulam ad Ephesios 20, 6, w: Patrologia Graeca, t. 62, s. 143.
} 
Rodzina była pierwszym środowiskiem religijnego wykształcenia ${ }^{14}$. Tak wielka rola wychowawcza rodziny nie miała nawet miejsca w rzymskim systemie społecznym ${ }^{15}$.

Ojcowie Kościoła upominali o chrześcijańskich obowiązkach rodziców. Zadaniem rodziców było nauczać podstawowych prawd wiary i zasad życia chrześcijańskiego. Wobec zagrożeń płynących z kultury pogańskiej dbano o zachowanie stylu życia prawdziwie religijnego. Kościół upominał, aby zachować czystość zwyczajów przez powstrzymywanie się od udziału w pogańskich zabawach, spektaklach czy zawodach sportowych (Tertulian, św. Jan Chryzostom, św. Augustyn). Jednak wpływ rodzinnej formacji religijnej na młodzież nie zawsze był duży. Wynikało to $\mathrm{z}$ faktu, że ludzie młodzi spędzali często dużo czasu poza domem za względu na szkołę czy rozrywkę ${ }^{16}$.

\section{Młodzież w środowisku średniowiecznej Civitas christiana}

Epoka średniowiecza to czas narodzin społeczeństwa chrześcijańskiego, które poprzez swoje instytucje i kulturę wywierało silny wpływ na cały proces nauczania i wychowania. Wychowanie miało charakter stanowy wynikający z porządku feudalnego z podziałem na duchowieństwo, rycerstwo, mieszczaństwo i chłopstwo. Młodych wychowywano przez wprowadzenie w obowiązki swego stanu określone przez tradycję i zwyczaje. Wspólną dla wszystkich stanów podstawą wychowania moralnego była religia nauczana przez duchowieństwo parafialne ${ }^{17}$.

W średniowieczu zmieniła się całkowicie sytuacja ewangelizacyjna i duszpasterska Kościoła. Zaczął zanikać katechumenat dorosłych i zaczęto chrzcić dzieci. Zrodziła się nowa sytuacja, w której należało nauczać wiary ludzi już ochrzczonych. Przyjęcie chrztu nie było celem katechezy, ale jej punktem wyjścia. Historycy katechezy mówią o modelu pochrzcielnym inicjacji chrześcijańskiej ${ }^{18}$. W odróżnieniu od wcześniejszej bardzo solidnej formacji w starożytnym katechumenacie program pracy duszpasterskiej stał się teraz dużo uboższy i polegał na prostym wykładzie najbardziej podstawowych prawd wiary w oparciu o Symbol wiary i Modlitwe Pańska. Z czasem zaczęto ubogacać proces nauczania. Tak było w czasach karolińskich, kiedy podjęto program odnowy życia religijnego. Najważniejsze ożywienie

14 Zob. P. Riché, Edukacja i kultura w Europie Zachodniej (VI-VIII w.), Warszawa 1995, s. 18.

15 Zob. M. Simoncelli, Lineamenti di Storia della pedagogia, w: Educare, t. I, red. P. Braido, Zürich 1962 , s. 49.

16 Zob. O. Pasquato, Pastorale giovanile (storia-1), dz. cyt., s. 781-782.

17 Zob. K. Bartnicka, I. Szybiak, Zarys historii wychowania, Warszawa 2001, s. 66-67.

18 Zob. G. Cavallotto, Il modello catechistico del catecumenato antico, w: Diventare cristiani. La catechesi come percorso formativo, red. L. Medei, Napoli 2002, s. 121-122. 
dokonało się później podczas odnowy zapoczątkowanej przez Sobór Laterański IV $^{19}$.

Podobnie jak w starożytności tak i w czasach średniowiecza nie było instytucjonalnej, zorganizowanej katechezy i duszpasterstwa młodzieży. Wprowadzenie w wiarę i życie chrześcijańskie dokonywało się w sposób naturalny i spontaniczny przez proces socjalizacji religijnej w różnych środowiskach chrześcijańskich, takich jak rodzina, szkoła, społeczeństwo i zgromadzenia liturgiczne w kościołach parafialnych. W literaturze z zakresu historii katechezy mówi się o średniowiecznym katechumenacie środowiskowym czy społecznym ${ }^{20}$.

Brak katechezy młodzieży wynikał również ze specyficznego sposobu postrzegania wieku młodzieńczego. Tak naprawdę to trzeba raczej mówić o nieobecności tego wieku w kulturze i społeczeństwie tamtych czasów. Dzieci były szybko włączane w świat dorosłych, w którym dokonywało się bezpośrednie przejście z dzieciństwa ku dorosłości. Mało uwagi poświęcano podziałowi rozwoju człowieka na kategorie wiekowe, chociażby z powodu bardzo krótkiego średniego wieku życia człowieka. Jeśli już pojawiały się kategorie typu infans, puer, adulescens i iuvenis, to stosowano je jednak mało precyzyjnie. Bardzo różnie, $\mathrm{z}$ resztą, pojmowano sam wiek młodości, od kilkunastu aż do nawet kilkudziesięciu lat ${ }^{21}$. Interesowano się przede wszystkim osobami dorosłymi, do których chciano upodobniać młodych. Brakowało jakiejkolwiek pedagogii wieku dziecięcego i młodzieńczego. Sytuacja ta zmieniła się dopiero w późniejszych epokach poczynając od humanizmu odrodzeniowego.

\subsection{Rodzina pierwszym środowiskiem formacji wiary}

Ludzie młodzi wynosili wiarę z domu. Rodzina pełniła funkcję dawnego katechumenatu, gdyż to właśnie w niej dokonywało się wprowadzenie w wiarę po przyjęciu chrztu. Kościół wspomagał rodzinę w tym zadaniu przez pouczenia kierowane do rodziców podczas niedzielnych i świątecznych kazań w kościołach. Odpowiedzialność katechetyczna wychowania młodych spoczywała na rodzicach.

\footnotetext{
19 Niektórzy autorzy nazywają zmiany dokonane decyzjami Soboru Laterańskiego IV „Zwrotem pastoralnym XIII wieku”. Zob. A. Vauchez, Zwrot duszpasterski w Kościele na Zachodzie, w: Historia chrześcijaństwa, t. 5, Ekspansja Kościoła rzymskiego 1054-1274, red. J.-M. Mayer, Ch. i L. Pietri, A. Vauchez, M. Venard; red. wydania polskiego J. Kłoczowski, Warszawa 2001, s. 612.

20 Zob. U. Gianetto, La catechesi nella storia: dagli inizi fino al rinnovamento conciliare, w: Andate e insegnate. Manuale di catechetica, red. E. Alberich, U. Gianetto, Leumann (Torino) 2002, s. 62-63.

21 Izydor z Sewilii wyróżnia następujące okresy życia człowieka: infantia 1-7 lat, pueritia 7-14 lat, adulescentia 14-28 lat, iuventus 28-50 lat, gravitas 50-70 lat, senectus (powyżej 70 lat). Zob. Craig B. McKee, Les enfants et la pénitence avant Latran IV (1215). De ludis puerilibus, w: La Maison-Dieu 172(1987), s. 90. Zob. też. J. Leclercq, Pédagogie et formation sprituelle du VIe au XIe siècle, w: La scuola nell'occidente latino dell'altomedioevo, Spoleto 1972, s. 255-290; F. Garelli, M. Offi, Giovani. Una vecchia storia?,Torino 1997, s. 6.
} 
Wielką wartość i skuteczność wychowawczą średniowiecznego katechumenatu rodzinnego podkreśla F. Blachnicki. Stwierdza on, że „przez blisko tysiąc lat nie było w Kościele żadnej nauki religii ani żadnej katechizacji. Mimo to Kościół się rozwijał i to nawet dynamicznie, był misyjny, ekspansywny, zmieniał życie ludzi. Powstała średniowieczna Civitas christiana, gdzie wszystkie dziedziny życia były przeniknięte duchem chrześcijańskim. Wszystko dlatego, że działał katechumenat rodzinny, domowy"22.

\subsection{Formacja młodych w średniowiecznych szkołach}

We wczesnym średniowieczu, w wiekach w VI i VII, zaczął zanikać starożytny system edukacji klasycznej i zaczęły powstawać szkoły chrześcijańskie. Początkowo były one w większości przeznaczone dla kandydatów do życia zakonnego i kapłańskiego, z czasem zaś zaczęły otwierać się na naukę młodzieży świeckiej. Była to jednak formacja bardziej religijna niż świecka. Wcześniejszy klasyczny program kształcenia oparty na siedmiu sztukach wyzwolonych (trivium - gramatyka, retoryka, dialektyka; quadrivium - geometria, astronomia, arytmetyka, teoria muzyki) stawał się właściwie już tylko „mglistym wspomnieniem”23. Duży wpływ na rozwój szkół kościelnych miały reformy Karola Wielkiego w VIII i IX wieku oraz późniejsze dwa sobory: Laterański III (1179) i Laterański IV (1215) ${ }^{24}$.

Szczegółowy charakter formacji ludzi młodych zależał od rodzaju poszczególnych szkół. W szkołach klasztornych formowano do życia zakonnego. Tego rodzaju szkoły powstawały na skutek intensywnego rozwoju życia monastycznego, zarówno na wschodzie jak i na zachodzie Europy. Na wschodzie formacja miała charakter bardziej religijny i ascetyczny (modlitwa, praca, lektura Pisma Świętego), na zachodzie zaś próbowano łączyć ascezę z nauką, dlatego też prowadzono naukę czytania i pisania, zakładano biblioteki klasztorne i skryptoria, praktykowano obowiązek lektury własnej i wspólnej ${ }^{25}$.

W szkołach biskupich i prezbiterialnych kształcono kandydatów do stanu duchownego. Wiele takich szkół powstało we wczesnym średniowieczu na ziemiach

${ }^{22}$ F. Blachnicki, Sympatycy czy chrześcijanie? Katechumenat na dzisiejsza godzinę, Kraków 2008, s. 66-67.

${ }^{23}$ Zob. Banniard, Wczesne średniowiecze na Zachodzie, Warszawa 1998, s. 155.

${ }^{24}$ Przywołane sobory zarządzały upowszechnienie szkół kościelnych oraz nakładały na kapituły katedralne obowiązek wyznaczenia specjalnego beneficjum dla magistra, aby mógł za darmo uczyć biedniejszych uczniów. Zob. III Sobór Laterański, kan. XVIII, w: Dokumenty soborów powszechnych, t. 2, red. A. Baran, H. Pietras, Kraków 2004, s. 193; Sobór Laterański IV, Konst. 11, O nauczycielach szkolnych, w: Dokumenty soborów powszechnych, t. 2, dz. cyt., s. 247.

${ }^{25}$ Zob. R. Murawski, Początki szkół chrześcijańskich, w: Ku doświadczeniu wiary. Ksiegga dedykowana Księdzu Profesorowi Andrzejowi Offmańskiemu w 70. rocznicę urodzin i 40. rocznicę pracy naukowo-dydaktycznej, red. K. Kantowski, W. Lechów, Szczecin 2012, s. 364-371. 
zachodniej Europy, w Galii i w Hiszpanii. Impulsem były postanowienia Synodów w Toledo w 527 roku i w Vaison w 529 roku wzywające do zakładania tych szkół ${ }^{26}$. W szkołach tych tak naprawdę nie tylko przygotowywano do zawodu, ale również kształcono i wychowywano.

Ważnym miejscem formacji młodzieży stały się szkoły parafialne. Powstały one ze szkół prezbiterialnych na wskutek otwarcia się ich na formację świeckich. Było to zasługą wspomnianego synodu w Vaison, którego postanowienia uważa się za powołanie szkół parafialnych ${ }^{27}$. Dzięki tym szkołom zaczęto kształcić uczniów świeckich. Podobnie jak w szkołach klasztornych i biskupich nauczanie miało charakter głównie religijny i było odizolowane od wpływów świeckich ${ }^{28}$.

\subsection{Młodzi w środowisku pierwszych uniwersytetów}

W powstających już od XII wieku uniwersytetach młodzi studiowali nie tylko nauki świeckie, ale i teologię. Teologia należała wraz z prawem i medycyną do wydziałów wyższych (wydział niższy obejmował studium sztuk wyzwolonych). Studia teologiczne zakończone doktoratem trwały najdłużej ze wszystkich nauk. Doktorat $\mathrm{z}$ teologii można było zdobyć dopiero po ukończeniu 25 lat życia ${ }^{29}$. Nauczając teologii prowadzono tym samym formację religijną młodych. Nie były to jednak działania obejmujące duże rzesze młodych. Największy uniwersytet w Paryżu mógł liczyć w XIII wieku około 1500 studentów ${ }^{30}$.

\section{4. Środowiska arystokratyczne i książęce}

Na uwagę zasługuje formacja młodzieży w bogatych rodzinach książęcych i arystokratycznych. Środowiska arystokracji świeckiej stanowiły obok mnichów i kleru ważną grupę społeczną, która prezentowała swój odrębny model życia. Młodych oddawano pod opiekę wykształconych nauczycieli, często duchownych. Pomocą w nauczaniu i wychowaniu były dobrze uposażone biblioteki zawierające książki służące nie tylko formacji politycznej i moralnej, ale i religijnej. We wczesnym średniowieczu młodzi książęta parę razy dziennie nawiedzali kościoły czy prywatne

\footnotetext{
26 Zob. P. Riché, Edukacja i kultura w Europie Zachodniej (VI-VIII w.), dz. cyt., s. 133-140.

27 Zob. Concilium Vasense, w: Monumenta Germaniae Historica, Legum Sectio III, Concilia aevi Merovingici, Hanover 1893, s. 56. Tekst kanonu nakazuje, aby proboszczowie gromadzili w parafiach młodych ludzi i przygotowywali ich na swoich następców. Powinni ich formować duchowo, uczyć psałterza, wprowadzać w lekturę Biblii i pouczać o prawie Bożym.

28 Zob. P. Riché, Edukacja i kultura w Europie Zachodniej (VI-VIII w.), dz. cyt., s. 470-471.

${ }^{29}$ Od 14 do 20 roku życia studiowano sztuki wyzwolone, od 20 do 25 roku życia studiowano na wydziale prawa i medycyny.

30 Zob. S. Litak, Historia wychowania, T. I. Do wielkiej rewolucji francuskiej, Kraków 2006, s. 65-72.
} 
kaplice. Byli zachęcani do czytania Biblii i odmawiania psalmów. Świeccy znali przypisywane Alkuinowi pismo De usu pslamorum. Prosili duchownych o teksty psalmów i komentarze do ksiąg biblijnych. Dhuoda, bogata arystokratka francuska z IX wieku, zachęcała swojego syna Wilhellma do odmawiania godzin brewiarzowych i recytowania psalmów przy wyznawaniu własnych win ${ }^{31}$.

Pomocą w formacji moralnej i religijnej były pisma nazywane zwierciadłami (specula). Stanowiły one pewnego rodzaju podręczniki życia chrześcijańskiego. W zależności od adresatów różniły się między sobą w zakresie formy i treści. Dominowały w nich treści moralne wskazujące jak prowadzić życie chrześcijańskie $\mathrm{w}$ danym stanie czy zawodzie. Wiele miejsca poświęcano cnotom moralnym oraz podkreślano znaczenie obowiązków wobec państwa ${ }^{32}$. Zwierciadła pisali królowie dla podwładnych, ojcowie dla synów, matki dla dzieci, biskupi dla wiernych. Najbardziej znanymi we wczesnym średniowieczu były dwa zwierciadła adresowane do świeckich: De institutione laicali Jonasza z Orleanu i pismo przywoływanej Dhuody Liber manualis ${ }^{33}$. Posługiwano się też poematami religijnymi czego przykładem jest poemat Otfrida z Weissenburga opisujący w pięciu księgach życie Jezusa. Autor napisał go, aby był pomocą dla nauczania młodych, którzy odkrywając piękno Ewangelii odrzucą sprośne pieśni swoich czasów ${ }^{34}$.

\subsection{Religijno-moralny ideał wychowania rycerskiego}

Wychowanie religijne znalazło swój wyraz także w wychowaniu rycerskim. Dzięki dużym wpływom Kościoła stan rycerski stał się stopniowo ideałem religijno -moralnym z własnym kodeksem zasad życia i postępowania. Było to wychowanie młodych oparte na konkretnych zasadach religijnych i etycznych. Rycerz chrześcijański miał trzy obowiązki służby: najpierw Bogu, potem swemu panu i swej kobiecie. Wśród różnych cnót do zdobycia nie wolno było zapomnieć o cnocie pobożności. Wychowanie odbywało się w kilku etapach: od 7 do 14 roku życia było się paziem na dworze króla, od 14 do 21 roku życia pełniło się funkcję giermka przy rycerzu, po ukończeniu 21 lat było pasowanie na rycerza. Obrzęd pasowania miał wiele treści o charakterze religijnym. Przed pasowaniem obowiązywał post, spowiedź i przyjęcie Komunii świętej. Poprzedzająca pasowanie noc była spędzana

31 Zob. Dhuoda, Manuel pour mon fils, rozdz. X. Introduction, texte critique, notes par P. Riché, Traduction par B. de Vregille, C. Mondésert, Paris 1975 (Sources Chrétiennes 225).

32 Zob. A. Vauchez, Duchowość średniowiecza, przekład z franc. H. Zaremska, Gdańsk 2004, s. 15.

33 Zob. W. Osial, Historia katechizmu. Geneza i rozwój katechizmu w Kościele katolickim od I do XVI wieku, Warszawa 2013, s. 181-184.

34 Zob. O. Pasquato, Pastorale giovanile (storia-2), w: Dizionario di pastorale giovanile, dz. cyt., s. 816 . 
na modlitwie w kościele. Rycerz składał przysięgę, która zobowiązywała go między innymi do strzeżenia religii i jej świętości oraz walki z wrogami chrześcijaństwa ${ }^{35}$.

\section{Wyzwania myśli pedagogicznej humanizmu}

Wraz z narodzinami humanizmu odrodzeniowego nastąpiła istotna zmiana w kulturze i myśli europejskiej. Odstąpiono od teocentryzmu średniowiecznego i nadprzyrodzonej wizji świata. W centrum uwagi pojawiły się wartości ludzkie i doczesne, które zaczęły wyznaczać nowe spojrzenie na człowieka i jego życie. To zainteresowanie się człowiekiem, nawiązujące do ideałów starożytnej Grecji i Rzymu, odnowiło cały proces wychowania i nauczania człowieka. Powstała nowa szkoła i pedagogika (studia humanitatis) ${ }^{36}$. Założenia edukacyjne były całkowicie nowe i rewolucyjne w konfrontacji z poprzednią epoką średniowiecza. To nie była sama wiedza wymagająca posłuszeństwa, ale przede wszystkim formacja osoby, jej rozwój duchowy, w aktywnym zaangażowaniu samego wychowanka.

W tej nowej sytuacji Kościół coraz większą uwagę zaczął skupiać na wychowaniu dzieci i młodzieży. Próbowano godzić idee humanizmu z wychowaniem chrześcijańskim młodzieży, czego dowodem są starania włoskiego humanisty Vittorino da Feltre (1378-1446) czy najznakomitszego przedstawiciela myśli pedagogicznej humanizmu Erazma z Rotterdamu (1467-1536). Pierwszy z nich w swojej szkole nazwanej Casa gioiosa (Dom radości) uczył harmonijnego wychowania w klimacie zaufania oraz przyjemnych, ale i zarazem poważnych obowiązków względem Boga i człowieka ${ }^{37}$. Erazm z Rotterdamu w swoich Colloquia (Rozmowy potoczne) omawia kwestię pobożnego wychowania młodzieży. Za warunki konieczne dobrego wychowania uważa uczestnictwo w kulcie (modlitwa i sakramenty) oraz zachowywanie przykazań. Wszystko opisuje w kontekście codziennego i zarazem nadprzyrodzonego życia młodego człowieka. To model pobożnego wychowania w duchu humanizmu, w którym wartości ludzkie łączy się z rozwojem wiary człowieka ${ }^{38}$.

\footnotetext{
35 Zob. S. Litak, Historia wychowania, dz. cyt., 77-78.

36 Zob. tamże, s. 87.

37 Zob. F. Casella, Storia della pedagogia. Vol. I. Dall'antichità classica all'Umanesimo-Rinascimento, Roma 2009, s. 450-452.

38 Zob. L. Csonka, Storia della catechesi, w: Educare. Sommario di scienze pedagogiche, t. III, red. P. Braido, Zürich 19643, s. 105. Erazm jest autorem znanego i zarazem ciekawego traktatu pedagogicznego O jak najwcześniejszym wychowaniu dzieci w duchu humanistycznym (1529). Za Arystotelesem głosi w nim, że w wychowaniu potrzebne są trzy czynniki: natura, ratio (wykształcenie) i exercitatio (ćwiczenie). Zob. Erazm z Rotterdamu, Pisma moralne. Wybór, Warszawa 1970, s. 56.
} 


\section{Reformy Soboru Trydenckiego - narodziny katechezy młodych w parafii}

Na przełomie XV i XVI wieku zrodziły się nowe inicjatywy duszpasterskokatechetyczne Kościoła podejmujące wyzwania płynące z przemian społecznych i kulturowych. Przede wszystkim intensywnie rozwijała się sieć szkół parafialnych w których zaczęto uczyć dzieci i młodzież. Najbardziej znaną i zarazem zorganizowaną inicjatywą były tzw. Szkoły Nauki Chrześcijańskiej powstałe w 1536 roku w Mediolanie z inicjatywy kapłana Castellino da Castello. Stały się one modelem dla wszystkich innych późniejszych szkól, tak we Włoszech jak i w Europie ${ }^{39}$. Wraz z rozwijającymi się szkołami powstawały stowarzyszenia i bractwa, których celem była troska o organizację szkół i ich sprawne funkcjonowanie. Jednym z pierwszych było Stowarzyszenie Sług Dzieciątek w Miłości powołane w 1539 roku Mediolanie przez samego Castellino da Castello ${ }^{40}$.

Impulsem do zainteresowania się formacją młodzieży były także zmiany społeczne i religijne tamtych czasów. Należało zaopiekować się dziećmi, które w wyniku wielu zaraz i wojen mających miejsce pod koniec XV wieku i na początku XVI, utraciły bliskich i potrzebowały opieki. Nie można pominąć również reformy protestanckiej, która pokazała, jak ważna jest formacja młodych w przekonywaniu do własnych nauk i poglądów ${ }^{41}$.

Wobec tych wszystkich wyzwań Kościół na Soborze Trydenckim podjął decyzję o wprowadzeniu obowiązku katechizacji dzieci i młodzieży w parafii. Jest to bardzo ważny moment, który należy uważać za narodziny oficjalnej katechezy ludzi młodych w Kościele. W ciągu wcześniejszych piętnastu wieków wychowanie i nauczanie religijne było powierzone rodzicom i rodzinom, teraz zaś otrzymało nową formę. Miejsce katechumenatu rodzinnego zastąpił katechumenat parafialny. Katecheza młodych przestała być inicjatywą jedynie zakonów czy bardziej gorliwych duszpasterzy, ale stała się urzędową formą katechezy Kościoła ${ }^{42}$.

Katecheza dzieci i młodzieży miała być organizowana we wszystkich parafiach i jej celem był przekaz podstawowych prawd wiary i zasad życia chrześcijańskiego.

\footnotetext{
39 Zob. A. Tamborini, La Compagnia e le Scuole della dottrina cristiana, Milano 1939; E. Paul, Geschichte der christlichen Erziehung, t. II. Barock und Aufklärung, Freiburg-Basel-Wien 1995, s. 102-104.

40 Zob. P. Braido, Lineamenti di storia della catechesi e dei catechismi. Dal "tempo delle riforme" all'età degli imperialismi (1450-1870), Leumann (Torino) 1991, s.138-139.

41 Zob. L. Csonka, Storia della catechesi, dz. cyt., s. 112; R. Murawski, Rys historyczny lekcji religii katolickiej w Europie, „Studia Katechetyczne” 7(2010), s. 27-28.

42 Zob. G. Cavallotto, Il Concilio di Trento e l'origine della catechesi moderna, w: Andate e insegnate. Commento all'Esortazione Apostolica "Catechesi tradendae”, red. C. Bonivento, Bologna 1980, s. 159; R. Murawski, Historia katechezy, w: Historia katechezy i katechetyka fundamentalna, red. J. Stala, Tarnów 2003, s. 79-80; tenże, Rys historyczny katechizacji dzieci w Kościele, w: Katecheza dzieci, red. M. Zając, Lublin 2009, s. 25-29.
} 
W postanowieniach Soboru Trydenckiego z dnia 11 listopada 1563 roku czytamy: „biskupi zatroszczą się, aby przynajmniej w niedziele i w inne dni świąteczne dzieci w poszczególnych parafiach były pilnie nauczane podstaw wiary oraz posłuszeństwa wobec Boga i względem rodziców, przez tych, do których to należy, a których $\mathrm{w}$ miarę potrzeby biskupi mogą przymusić również za pomocą kar kościelnych, bez względu na przywileje i zwyczaje"43.

\section{Potrydenckie inicjatywy formacji ludzi młodych (do I połowy XVIII wieku)}

Nakaz organizowania katechizacji młodych wyzwolił różnorodne inicjatywy katechetyczne i duszpasterskie. Coraz więcej ludzi młodych zaczęło brać udział nie tylko w niedzielnej i świątecznej katechizacji, ale również w innych formach parafialnego życia religijnego. Impulsy odnowy pochodziły z Soboru Trydenckiego, lokalnych synodów, od hierarchów kościelnych i władców świeckich. Bardzo ważna była odnowa pastoralna Soboru Trydenckiego mobilizująca biskupów i podległych im kapłanów do zaangażowania się w duszpasterstwo. Biskupi zostali wezwani do troski o przepowiadanie i katechetyczne nauczanie. Mieli oni gorliwie nauczać oraz mobilizować do nauczania podległych im duchownych ${ }^{44}$. Nie bez znaczenia było też zobowiązanie biskupów do przebywania na terenie własnej diecezji (nakaz rezydencji) ${ }^{45}$. Podobnie przypominała o tych obowiązkach encyklika Benedykta XIV Etsi minime z $1742 \mathrm{roku}^{46}$. Biskupi podczas wizyt duszpasterskich katechizowali młodych, odpytywali ze znajomości doktryny. Tak postępowali wzorcowi pasterze tamtych czasów jak św. Karol Boromeusz czy św. Franciszek Salezy.

Katechizacja dokonywała się w klimacie bardzo szybkich i głębokich przemian religijnych, kulturowych, społecznych, gospodarczych i politycznych (reforma protestancka, wojny, rewolucje polityczne, techniczne i gospodarcze). Wszystkie te wydarzenia wymagały reakcji ze strony Kościoła. W wyniku podejmowanych

\footnotetext{
${ }^{43}$ Sobór Trydencki, Sesja 24, Dekret o reformie, Kanon 4, s. 743, w: Dokumenty soborów powszechnych. Tekst łaciński i polski, t. IV (1511-1870), Lateran V, Trydent, Watykan I, red. A. Baron, H. Pietras, Kraków 2004.

${ }_{44}$ Zob. Sobór Trydencki, Sesja 5, Dekret o nauczaniu igłoszeniu, rozdz. 2, dz. cyt., s. 245-249; Tenże, Sesja 24, Dekret o reformie, Kanon 4, s. 743 i Kanon 7, s. 747, w: dz. cyt. Była to reakcja Kościoła na sytuacje, w których biskupi mało angażowali się w duszpasterstwo. Były takie sytuacje, w których biskupi dużo bardziej interesowali się wydarzeniami kultury renesansu i humanizmu niż problemami związanymi z życiem religijnym ludzi. Zob. G. Cavallotto, Il Concilio di Trento e l'origine della catechesi moderna, art. cyt., 151

45 Zob. Sobór Trydencki, Sesja 6, Dekret o rezydowaniu biskupów i innych niższych duchownych, dz. cyt., s. 319-325.

46 Zob. Benedicto XIV, Etsi minime (7.II.1742), w: Codicis Iuris Canonici Fontes, t. I, Typis Polyglottis Vaticanis 1947, s. 715-716.
} 
działań zaczęła tworzyć się nowa praktyka katechetyczna i pastoralna, która stawała się coraz bardziej bogata, ustabilizowana i uporządkowana. Jej świadectwem są zapisy w dwóch dokumentach pochodzących z Synodu Rzymskiego zwołanego przez papieża Benedykta XIII w 1725 roku. Na uwagę zasługuje szczególnie rozdział IV opisujący działania katechetyczne i pastoralne wobec dzieci i młodzieży oraz dwie instrukcje o przygotowaniu do spowiedzi i pierwszej Komunii ${ }^{47}$. Dokumenty rysują obraz katechezy, która była szeroko rozpowszechniona w XVII i XVIII wieku $^{48}$. Nie można pominąć również wspominanej już encykliki Benedykta XIV Etsi minime z 1742 roku, która bardzo mocno wskazywała na obowiązek nauczania najważniejszych prawd wiary i zasad moralności nie tylko dzieci i młodzieży, ale również dorosłych i ludzi starych ${ }^{49}$.

\subsection{Formy katechizacji parafialnej}

Inicjatorami działań katechetycznych byli duchowni w parafiach, którym powierzono misję nauczania. Benedykt XIV w encyklice Etsi minime zobowiązywał curatores animarum nie tylko do przepowiadania wiernym w święta, ale także do nauczania prawd wiary młodych ${ }^{50}$. Spotykamy różne formy katechizacji parafialnej młodzieży. Najbardziej rozpowszechnioną były spotkania w niedziele i święta po południu przed Nieszporami. Niektóre synody nakazywały jeszcze nauczać w dni powszednie Wielkiego Postu. Przestrzegano podziału na klasy z odzieleniem chłopców od dziewcząt ${ }^{51}$. Proboszczowie byli obligowani do prowadzenia takich niedzielnych szkó ${ }^{52}$. Nalegano, aby proboszcz osobiście prowadził nauki i dbał o ich jakość. Musiał on zachęcać i upominać rodziców do posyłania dzieci na katechizację. Powinien posiadać listę uczestników, kontrolować obecność, mobilizować leniwych. Często szkoły te były prowadzone przez różne Bractwa i Konfraternie (Szkoły Doktryny Chrześcijańskiej). Wśród treści nauczania był Symbol wiary, przykazania kościelne, sakramenty, Ojcze nasz, Pozdrowienie Anielskie, cnoty

\footnotetext{
47 Zob. Concilium Romanum, Titulus I. De Summa Trinitate et Fide Catholica: Cap. IV. Parochorum munera commemorantur: Pueros Doctrinam Christianam ediscendi methodus exhibetur, w: Acta et decreta sacrorum conciliorum recentiorum. Collectio lacensis, t. I, Freiburg im Breisgau, 1870, s. 347-348; Instructio pro parvulis prima vice ad Sacramentalem Confessionem admittendis (n. XIX), dz. cyt., s. 456-461; Instructio pro illis, qui prima vice accedunt ad Sacram Mensam (n. XXX), dz. cyt., s. 461-466.

48 Zob. P. Braido, Lineamenti di storia della catechesi e dei catechismi, dz. cyt., s. 149.

49 Zob. Benedicto XIV, Etsi minime, dz. cyt., s. 715-720.

50 Zob. tamże, s. 716.

51 Zob. P. Braido, Lineamenti di storia della catechesi e dei catechismi, dz. cyt., s. 166.

52 Zob. Concilium Romanum, Cap. IV. Parochorum munera commemorantur: Pueros Doctrinam Christianam ediscendi methodus exhibetur, dz. cyt., s. 347-348.
} 
i grzechy, formuły aktów wiary, nadziei, miłości i pokuty ${ }^{53}$. Pojawiają się zalecenia, aby oddzielenie organizować katechezę dla tych młodych, którzy wstydzą się uczyć razem z młodszymi. Wyraźnie odróżniano młodych od dzieci i nazywano ich aevo grandiores (Synod w Mondovi 1763) czy aetate provectiores (synod w Fossano 1778) ${ }^{54}$.

Innym rodzajem katechizacji był udział młodzieży w nauczaniu skierowanym do wszystkich wiernych. Nauka przybierała wówczas rożne formy. Pierwszą z nich było nauczanie doktryny podczas Mszy Świętej w czasie kazania. Zamiast kazania uczono katechizmu. Często miało to miejsce w sytuacjach, kiedy wierni nie mogli przybyć w innym czasie do kościoła ${ }^{55}$. Proboszczowie czytali wówczas nauki zawarte w różnych instrukcjach katechetycznych opartych na Katechizmie Rzymskim czy też na innych katechizmach przygotowanych do katechizacji. Przykładem takiej instrukcji jest Instruction du Chrétien kardynała Richelieu z 1618 roku przeznaczona dla proboszczów diecezji Luçon. Służyła ona do nauki wiary podczas niedzielnych kazań ${ }^{56}$.

Inną formą wspólnej katechizacji było oddzielne nauczanie katechizmu poza Mszą Świętą. Odbywało się ono po katechizacji dzieci, tuż przed Nieszporami bądź w ich trakcie. Przykładem może być katechizm świąteczny w tzw. „małych szkołach” we Francji w połowie XVII wieku. Jego początki miały miejsce w Escole paroissiale przy kościele św. Mikołaja du Chardonet w Paryżu w 1654 roku ${ }^{57}$.

Należy również zauważyć katechezę podstawową dla prostego ludu polegającą na wspólnym recytowaniu najprostszych modlitw i prawd wiary. Uczono się przez wspólne powtarzanie tekstów przed Mszą Świętą, w jej trakcie lub po jej zakończeniu. Niekiedy była to jedyna forma katechizacji, szczególnie na terenach wiejskich.

Wreszcie łączono naukę prawd wiary z głoszeniem słowa Bożego w czasie niedzielnych kazań. Tak było na przykład w czasach św. Karola Borromeusza, który nakazywał rozszerzać kazania o wyjaśnienia modlitw i prawd nauki wiary ${ }^{58}$. Niektóre francuskie tłumaczenia i edycje Katechizmu Rzymskiego zawierały na przykład

\footnotetext{
53 Zob. P. Braido, Lineamenti di storia della catechesi e dei catechismi, dz. cyt., s. 166.

54 Zob. tamże, s. 167.

55 Takie rozwiązanie było lepsze dla samych proboszczów, szczególnie dla tych, którzy mieli trudności z przepowiadaniem. Mając do dyspozycji Instrukcje katechetyczne nie musieli głosić kazań. Ponadto proboszczowie nie musieli dwa razy nauczać w ciągu dnia. Byli przekonani, że realizują w ten sposób zarówno obowiązek nauczania doktryny młodych jak i powinność praedicatio verbi Dei wobec dorosłych.

56 Instrukcja nakazuje, aby nauczać prawd wiary według następującego porządku: Symbol wiary, Dekalog, Pater noster, sakramenty. Była to cykliczna lektura niedzielna podzielona na 28 lekcji. Czytanie publiczne nie powinno przekraczać 15 minut. Zob. J. Joncheray, «L'instruction du chrétien» de Richelieu: prône ou catéchisme?, w: Aux origines du catéchisme en France, red. P. Colin, E. Germain, J. Joncheray, M. Venard, Paris 1989, s. 229-246.

57 Tego rodzaju nauczaniu świątecznemu służył późniejszy katechizm J.-B. Bossueta z 1687 roku, który dzielił święta na trzy kategorie: święta Pańskie, maryjne i świętych. Zob. P. Braido, Lineamenti di storia della catechesi e dei catechismi, dz. cyt., s. 169.
}

58 Zob. Tamże, s. 176. 
indeksy, w których tekstom niedzielnych Ewangelii były przypisane poszczególne prawdy wiary (np. edycja w Bordeaux w 1578 roku).

Próbowano kontrolować znajomość prawd wiary u ludzi młodych. Zalecano, aby nie dopuszczać do I Komunii i do sakramentu małżeństwa tych, którzy nie znali podstawowych prawd takich jak Credo, Pater noster i Ave Maria ${ }^{59}$. Jakkolwiek zalecenia były wymagające, to jednak ignorancja religijna pozostawała cały czas bardzo duża ${ }^{60}$.

\subsection{Katechizm - podstawowe narzędzie nauczania}

Nauczanie ludzi młodych wymagało odpowiednich pomocy, dlatego też nastąpił intensywny rozwój katechizmów. W historii katechezy mówi się o początku ery katechizmu ${ }^{61}$. W ich opracowywaniu ważną rolę odegrali biskupi diecezjalni, którzy na mocy decyzji Soboru Trydenckiego otrzymali prawo opracowywania własnych katechizmów i modyfikowania katechizmów wcześniej używanych ${ }^{62}$.

Powstało bardzo dużo różnych katechizmów. Najbardziej rozpowszechnionymi były katechizmy powstałe w XVI wieku. Należy wskazać na katechizmy pisane do młodych uczących się w ówczesnych szkołach. Można przywołać Interrogatorio Castellino da Castello, szeroko rozpowszechnione w Szkołach Doktryny Chrześcijańskiej, katechizmy św. Piotra Kanizjusza napisane dla użytku w kolegiach jezuickich (Summa doctrinae christianae z 1555 roku, Parvus catechismus catholicorum z 1559 roku), Catéchisme et sommaire de la religion chrétienne E. Augera z 1563 roku i katechizmy R. Bellarmina: Mały Katechizm z 1597 i Duży Katechizm z 1598 roku $^{63}$. Katechizmy te miały wiele tłumaczeń i wydań. Powstało jeszcze wiele innych katechizmów w różnych krajach. Biskupi korzystali ze swoich uprawnień i wprowadzali nowe katechizmy uwzględniające lokalne uwarunkowania ${ }^{64}$.

\footnotetext{
59 Zob. Tamże, s. 170, 222-223.

60 Zob. P. Stella, I catechismi in Italia e in Francia nell'età moderna. Proliferazione tra analfabetismo e incredulità, w: Il catechismo ieri e oggi. Studi sul significato dei catechismi nel passato e nel presente della catechesi della Chiesa, red. E. Alberich, U. Gianetto, Leumann (Torino) 1987, s. 31-45.

61 Zob. W. Osial, Historia katechizmu, dz. cyt., s. 227-229; Ch. Wackenheim, Breve storia della catechesi. Tradizione e novità, tłum. z francuskiego M. A. Cozzi, Bologna 1985, s. 39.

62 Zob. R. Murawski, Geneza i rozwój katechizmu w Kościele katolickim, w: W co Kościół wierzy i z czego żyje, red. T. Panuś, Kraków 2004, s. 171.

63 Zob. W. Osial, Historia katechizmu, dz. cyt., s. 242-314.

64 Powstające katechizmy często podlegały wpływom teologicznym, nawet politycznym (Hiszpania, Austria, Francja). Zob. P. Braido, Lineamenti di storia della catechesi e dei catechismi, dz. cyt., s. $156-165$.
} 


\subsection{Nauczanie i wychowanie religijne w szkołach}

Kościół wzywał, aby nauczyciele we wszystkich szkołach nie zapominali o nauczaniu religijnym. Od czasów narodzin katechizmu zwiększyła się troska o wychowanie religijne młodych studentów w szkołach, czego dowodem są pierwsze katechizmy Kanizjusza czy Augera. Skłaniały ku temu również racje społeczne i polityczne, aby formować według własnej nauki tych, którzy w przyszłości podejmą ważne funkcje cywilne i kościelne. Istotne były postanowienia Soboru Laterańskiego V (1512-1517), aby w szkołach ludowych wraz z przekazem ogólnej wiedzy nauczać również o wierze ${ }^{65}$.

Zalecenia soborowe znajdowały odzwierciedlenie w wielu decyzjach Kościołów lokalnych. Bardzo wyraźnie wybrzmiewa pouczenie, aby nauczyciele nie czuli się zwolnieni z obowiązku wychowania chrześcijańskiego. Oczywiście tego rodzaju nakazy nie zawsze znajdowały akceptację i realizację ze strony nauczycieli. W wielu przypadkach wszystko kończyło się tylko na prośbach czy upominaniu. Jeśli natomiast chcieli, nauczyciele mogli nauczać katechizmu w czasie swoich lekcji czy też osobiście angażować się w katechizację w parafii i obligować wychowanków do uczestnictwa w niej ${ }^{66}$. Nalegano, aby uczyć wiary w rozwijających się tzw. małych szkołach (scholae minores) uczących podstaw wiedzy pisania, czytania i liczenia. Były one zarządzane przez parafie, kolegia kanonickie, bractwa, zakony czy władze świeckie. Rozwijały się intensywnie w Hiszpanii, Francji, Włoszech ${ }^{67}$. Dbano o nauczanie religijne również w szkołach wyższego stopnia nazywanych „collegia latinitatis”. Wreszcie nie można pominąć ogromnego dzieła nauczania religijnego w szkołach prowadzonych przez zakony. Wielkie zasługi mają jezuici, oratorianie, barnabici, ojcowie somascy, pijarzy, bracia szkolni.

\footnotetext{
65 Według Soboru „przełożeni szkół i nauczyciele powinni nauczać i odpytywać swoich chłopców czyli uczniów nie tylko w zakresie gramatyki, retoryki i pozostałych tego typu sztuk, a także będą zobowiązani nauczać tego, co dotyczy religii, jakie są przykazania Boże, artykuły wiary, święte hymny i psalmy, żywoty świętych, a w dni świąteczne nie mogą uczyć ich niczego innego, jak tylko rzeczy dotyczących religii i dobrych obyczajów. Są zobowiązani kształcić ich w nich, do nich zachęcać i nakłaniać, na ile mogą. Mają chodzić do kościołów nie tylko na msze, lecz także na nieszpory i słuchanie liturgii godzin, i podobnie skłaniać uczniów do słuchania kazań i nauk, i nie mogą im wykładać niczego przeciwko dobrym obyczajom ani co by prowadziło do bezbożności”. Zob. Sobór Laterański V, Sesja 9, Bulla II/C. Reforma kurii i innych instytucji, w: Dokumenty soborów powszechnych. Tekst łaciński i polski, t. IV (1511-1870), dz. cyt., s. 97-99.

66 Zob. P. Braido, Lineamenti di storia della catechesi e dei catechismi, dz. cyt., s. 196-197

67 Zob. tamże, s. 197-200.
} 


\section{Oświecenie - formacja młodzieży na lekcji religii w szkole}

Jakkolwiek w okresie potrydenckim nauczanie religijne było obecne w szkołach, to jednak nauka religii pełniła rolę drugorzędną. Nie było to nauczanie systematyczne, gdyż lekcje odbywały się nieregularnie i sama szkoła nie była obowiązkowa. Głównym miejscem formacji religijnej cały czas pozostawała parafia. Istotna zmiana nastąpiła w epoce oświecenia w drugiej połowie XVIII wieku, kiedy wraz z narodzinami nowej myśli filozoficznej dokonały się również ważne zmiany w spojrzeniu na wychowanie człowieka. W centrum znalazła się potęga rozumu człowieka, a w nauczaniu zauważano szansę na zmianę świata. Doprowadziło to do swoistego rodzaju „rewolucji szkolnej”. Zaczęto reformować organizację szkolnictwa. Po kasacie zakonu jezuitów (1773) szkoła zaczęła przechodzić w ręce państwa. Zaczęto wprowadzać powszechny obowiązek podstawowego nauczania (Prusy 1717; Austria 1774; Komisja Edukacji Narodowej w Polsce 1773-1794) ${ }^{68}$.

Ta nowa rzeczywistość szkolna wprowadziła bardzo duże zmiany w nauczaniu religijnym młodzieży. W ich wyniku nauka religii znalazła się w programie szkolnego nauczania i wysunęła się na pierwszy plan pośród całej aktywności szkoły. $\mathrm{W}$ ten sposób cały proces wychowania religijnego został przeniesiony z parafii do szkół. Modelem wzorcowym dla wielu krajów była organizacja i struktura oświaty w Austrii za czasów Marii Teresy. Wielkie zasługi dla jej rozwoju jak i również dla organizacji samej lekcji religii miał J. I. Felbiger (1724-1788), wielki reformator szkolnictwa tamtych czasów ${ }^{69}$.

\section{Próby odnowy katechezy młodzieżowej (XIX wiek)}

Wpisanie nauki religii w system nauczania szkolnego przyniosło dużo korzyści, ale zrodziły się też i pewne niebezpieczeństwa. Katecheza zaczęła zatracać swoje eklezjalne znaczenie jako proces wychowania w wierze. Zaczęto uważać ją za przedmiot szkolny uwypuklający bardziej wiedzę niż formację wiary. Równie niebezpieczne było wyrwanie katechizacji z jej naturalnego środowiska jakim jest parafia i rodzina. Tym samym nastąpił powolny proces kryzysu katechezy parafialnej i rodzinnej. Parafie zaczęły zwalniać się z obowiązku katechizacji, natomiast rodzice zaczęli wierzyć, że to szkoła jest odpowiedzialna za formację religijną ${ }^{70}$.

Tego rodzaju niebezpieczeństwa wyzwoliły niepokoje w różnych środowiskach katechetycznych. Dołączyły się do tego zagrożenia laicyzacji i dechrystianizacji płynące z niewdanej rewolucji francuskiej i kultury oświecenia. Zaczęto podejmować działania na rzecz odnowy religijnej, szczególnie na drodze ożywienia parafialnej

${ }^{68}$ Zob. R. Murawski, Rys historyczny lekcji religii katolickiej w Europie, art. cyt., s. 41.

69 Zob. tamże, s. 40-43.

${ }^{70}$ Zob. tamże, s. 45-46. 
formacji ludzi młodych. Niestety nie były to liczne inicjatywy. Podtrzymywano tradycyjne formy duszpasterstwa. Wciąż dominowały pamięciowe nauki oparte na katechizmach Kanizjusza, Bellarmina, Bousseta czy Deharba, czasem z niewielkimi próbami akomodacji czy modyfikacji. Katecheza zachowywała charakter klasycznego dwumianu docere rudimenta fidei e paserce sacramentis ${ }^{71}$.

Do troski o młodzież wzywali papieże. Papież Pius VII w encyklice Diu satis (1800) prosił biskupów, aby otoczyć opieką ludzi młodych, którzy dużo bardziej od dorosłych są podatni na zło ${ }^{72}$. W podobnym duchu nauczał Pius VIII w encyklice Traditi humilitati (1829) prosząc o obronę młodych przed zgubnymi wpływami innych nauk w szkołach wyższych i uniwersytetach ${ }^{73}$. Temat wychowania młodzieży był także bliski Piusowi IX, który wskazywał na zagrożenia dla wiary ludzi młodych płynące z nowej kultury ${ }^{74}$.

Wśród nowych inicjatyw ożywiania formacji młodych można przywołać paryskie konferencje dla studentów w parafii św. Sulpicjusza prowadzone przez D. Luc Antoine de Frayssinousa (1765-1841) w latach w latach 1803-1809 i 1814-1820. Od samego początku gromadziły rzesze młodych (cztery tysiące). Miały na celu obronę wiary przed zagrożeniami ówczesnej kultury. Podobny charakter apologetyczny miały równie znane konferencje w kościele Notre-Dame w Paryżu ${ }^{75}$.

W przywoływanej parafii św. Sulpicjusza w Paryżu organizowano także katechezy dla młodych według znanej już od XVII wieku metody sulpicjańskiej. Ich organizatorem i wielkim propagatorem w XIX wieku był Felix Dupanloup (1802-1878). Był to nie tylko przekaz wiedzy, ale przede wszystkim formacja chrześcijańska. Celem katechezy było prowadzenie do nawrócenia, wiedza zaś miała służyć formacji. Wykorzystywano różnego rodzaju celebracje liturgiczne. Obok nauki katechizmu było dużo modlitw, pieśni i pobożnych zachęt. Wszystko miało miejsce w oddzielnej kaplicy przeznaczonej na naukę katechizmu. F. Dupanloup szukał młodych, którzy po pierwszej Komunii przestali uczęszczać na katechizację. Pisał dla nich odpowiednie katechizmy ${ }^{76}$.

Wreszcie warto zauważyć szeroką rzeczywistość wychowania religijnego obecnego w rozwijających się prężnie w XIX wieku różnorodnych szkołach i dziełach prowadzonych przez Kościól, szczególnie zakony. Zrodziły się różnorodne pedagogie zgromadzeń zakonnych, szczególnie żeńskich. Można wskazać na polskie pedagogie sióstr niepokalanek, zmartwychwstanek, nazaretanek, służebniczek czy

\footnotetext{
${ }_{71}$ Zob. P. Braido, Lineamenti di storia della catechesi e dei catechismi, dz. cyt., s. 372.

72 Zob. Pius VII, Encyklika Diu satis, n. 13, w: Bullari Romani Continuatio, T. XI, s. 23.

73 Zob. Pius VIII, Encyklika Traditi humilitati, n. 7, w: Bullari Romani Continuatio, T. XVIII, s. 19.

74 Zob. Pius IX, List apostolski Cum nuper do biskupów Dwóch Sycylii (1858), w: Acta Pii IX Papae,

T. III, s. 12; Tenże, Encyklika Nostis et Nobiscum (1849), w: Acta Pii IX Papae, T. III, s. 12

75 Autorami konferencji byli H. Lacordaire (1802-1861) i G. Xavier de Ravignan (1795-1858). Zob.

P. Braido, Lineamenti di storia della catechesi e dei catechismi, dz. cyt., s. 370-372.

${ }^{76}$ Zob. E. Germain, Langages de la foi a travers l'histoire. Mentalités et catéchèse, approche d'une étude des mentalités, Paris 1972, s. 157-166.
} 
urszulanek ${ }^{77}$. W służbie młodym zaczęły powstawać oratoria i centra młodzieżowe, które przygarniały młodzież w święta i w dni powszednie. Uczono w nich katechizmu i zasad życia chrześcijańskiego. Jakkolwiek dzieło narodzin oratoriów sięga jeszcze XVI i XVII wieku (Bractwa Doktryny Chrześcijańskiej, dzieło św. Karola Boromeusza i św. Filipa Nereusza), to jednak w XIX wieku rozkwit oratoriów był bardzo duży. Najbardziej znane jest dzieło św. Jana Bosko w Włoszech. We Francji duże zasługi mają P. Allemand i J. Timon-David w Marsylii i P. Chevrier i jego Catéchisme du Prado w Lyonie ${ }^{78}$.

Zarysowane próby odnowy katechezy młodzieży w XIX wieku wprowadzają w szeroką dyskusję nad sytuacją katechezy młodzieżowej dzisiaj. Wyzwania kulturowe epoki oświecenia i czasów rewolucji francuskiej pozostają wciąż aktualne. Trudnościom lekcji religii w szkole towarzyszy kryzys katechezy parafialnej i rodzinnej. Teoria katechetyczna wypracowała model korelacji środowiskowej i zachęca do podejmowania działań katechetycznych w parafii. Problem jest jednak duży, gdyż wielu ludzi pozostaje obojętnymi na kierowane do nich zaproszenie. Historia pokazuje, że zawsze szukano nowych dróg, aby dotrzeć do młodych. Zachęca nas dzisiaj do nowych poszukiwań, aby nie utracić tych, do których należy przyszłość Kościoła.

\section{Zarys historii nauczania i wychowania religijnego młodzieży}

Artykuł jest próbą ukazania najważniejszych inicjatyw formacji religijnej młodzieży w Kościele począwszy od starożytności aż po koniec XIX wieku. Wszystko zostaje ukazane w ścisłej relacji edukacji religijnej młodych z całym procesem rozwoju katechizacji w Kościele. Autor analizuje wychowanie młodych w następujących epokach i związanych z nimi wydarzeniami: starożytność chrześcijańska, civitas Christiana w średniowieczu, odrodzenie z prądami humanizmu, zalecenia Soboru Trydenckiego, potrydenckie inicjatywy duszpasterskie, oświecenie ze szkolną lekcją religii i próby odnowy katechezy młodzieżowej w XIX wieku. Na koniec stwierdza się, że przedstawione próby odnowy katechezy młodzieży w XIX wieku wprowadzają w szeroką dyskusję nad sytuacją katechezy młodzieżowej dzisiaj.

Słowa kluczowe: historia wychowania religijnego, katecheza młodzieży

77 Zob. Pedagogie katolickich zgromadzeń zakonnych. Historia i współczesność, T. I. red. J. Kostkiewicz, Kraków 2012; T. II. red. J. Kostkiewicz, K. Misiaszek, Kraków 2013.

78 Zob. A. Favale, Pastorale giovanile (storia-3), w: Dizionario di pastorale giovanile, dz. cyt., s. 836. 


\section{OUTLINE OF THE HISTORY OF RELIGIOUS EDUCATION OF YOUNG PEOPLE}

The article is an attempt to show the most important initiatives in the Religious Education of the youth undertaken by the Church from ancient times until the end of the XIX century. This reflection gives only a general outline of the topic and points to the most important milestones in Religious Education. The close relationship of Religious Education of young people to the whole process of the development of catechesis in the Church is explored. The formation of Religious Education is a part of the catechetical Church's pastoral ministry. The author analyzes the education of young people in the following historical epochs, highlighting key events: Christian antiquity, civitas Christiana in the Middle Ages, Renaissance with its humanistic trends, instructions of the Council of Trent, after Trident pastoral initiatives, Enlightenment with religion taught as school-lessons, and finally the attempt to renew youth catechesis in the XIX century. The summary concludes that the attempts at renewal of catechesis in the XIX century opened up a wide-ranging discussion regarding difficult and complicated facets which apply to the youth's catechesis today.

Keywords: history of religious education, youth catechesis 